\title{
An Improved Instrument for Measuring Filter Rod Pressure Drop*
}

\author{
by R. L. Dixon
}

Research Laboratories, Tennessee Eastman Company, Division of Eastman Kodak Company, Kingsport, Tennessee, U.S.A.

\section{- INTRODUCTION}

The need for more world-wide uniformity and consistency in the measurement of filter rod pressure drop or draw resistance has been recognized. Methods have been pursued within the Technology Study Group of the international tobacco research organization, Coresta*\%, for the past several years (1). This need has been confirmed by collaborative pressure-drop studies $(2,2 a)$ and by difficulties encountered in duplicating the calibration of commercially available orifice-type standards used for setting the air flow rate in pressure-drop instrumentation. The instrument described is a significant step toward meeting the need. It represents a culmination of the work on laminar-flow capillary standards (3). It incorporates modern electronic pressure-drop measuring techniques, and, more specifically, it includes a built-in laminar-flow calibration standard. Building the calibration standard into the instrument eliminates some of the problems of external standards, such as the probability of calibration shift resulting from dirty capillaries and the need for handling

* Received for publication: 21st April, 1978.

$\therefore$ Cooperation Centre for Scientific Research Relative to Tobacco, 53 Quai d'Orsay, F-75340 Paris, Cedex 07. several external capillaries. The instrument is designed so that the pressure drop measured conforms with the definition of pressure drop recommended by Coresta.

\section{MATERIALS AND METHODS}

Theory

A primary consideration in the design of the instrument was the Coresta-recommended definition of pressure drop of filter rods or cigarettes adopted by the Technology Study Group during the 1971 Rome session (4). The main specifications of the Coresta definition are that the standard volumetric air flow rate of $17.5 \mathrm{ml} / \mathrm{s}$ be measured at the point of exit from the sample and that the air entering the sample must be at $22{ }^{\circ} \mathrm{C}, 60 \%$ relative humidity, and $760 \mathrm{mmHg}$ barometric pressure.

The instrument contains a laminar-flow calibration standard for setting the standard air flow rate. The calibration standard chosen is a commercially available device that effectively contains a multitude of parallel laminarflow capillaries. Laminar-flow capillary standards have previously been described in the literature (3). Two de- 
Figure 1. Laminar-flow capillary standards.

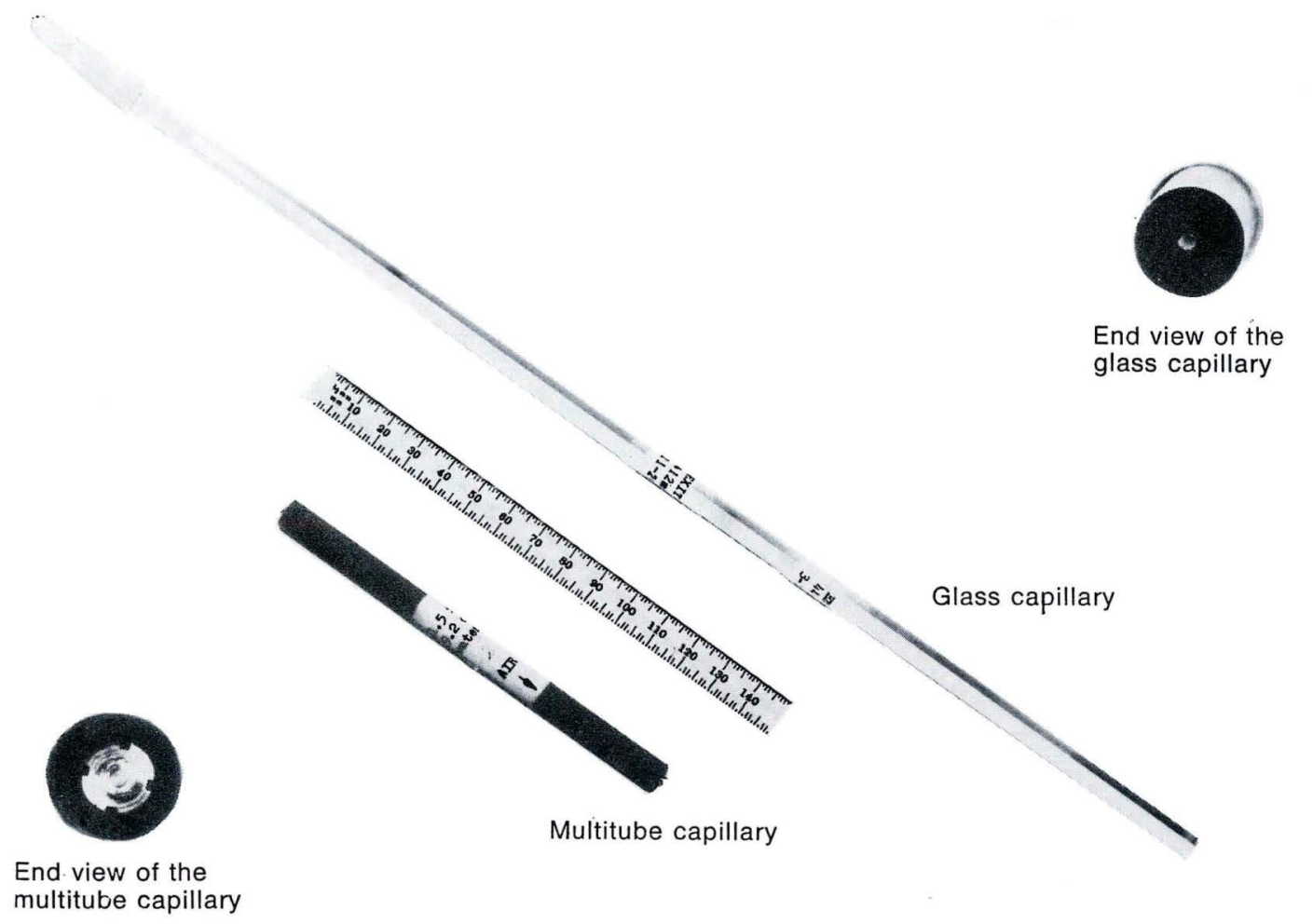

signs of capillary standards used for setting the flow rate in pressure-drop instrumentation that were developed prior to the development of the new instrument are shown in Figure 1. The glass capillary above the ruler has a single hole and a tapered-joint fitting. The multitube capillary below the ruler is more compact, light-weight, and about the size of a filter rod. It has a multislotted aluminum core that is assembled into a polyethylene sheath. The standards were designed to be insensitive to changes in ambient air conditions that could affect their calibrated pressure drop.

The pressure drop of laminar-flow capillaries is insensitive to changes in ambient air density if the capillary is designed so that a major portion of its pressure drop results from fully developed laminar flow. Air density changes could result from air temperature variations or barometric pressure changes associated with either weather conditions or elevation differences between manufacturing locations. The Hagen-Poisenille (6) equation, which relates volumetric flow rate to pressure drop for fully developed laminar flow, shows that the pressure drop in laminar flow is only dependent on fluid viscosity, capillary length, capillary diameter, and volumetric flow rate, and that the pressure drop is independent of fluid density. However, a real capillary having laminar flow will have entrance and exit pressure-drop effects which are air-density and velocity-dependent. These entrance and exit effects can be made negligible by designing the capillary so that the laminar-flow pressure-drop contribution is large compared to the pressure-drop contribution from the entrance and exit effects (7).
Building the laminar-flow calibration standard into the pressure-drop instrument requires that the standard have undetectable entrance and exit pressure-drop effects in the normal operation of the instrument. This requirement is necessary, not only because ambient air conditions change, but also because the pressure drop of the samples inserted upstream of the calibration standard is quite variable. To minimize the entrance and exit effects, the flow should be divided among many parallel capillaries. Such a device is commercially available (Laminar-Flow Element, Meriam Instrument Company, Cleveland, Ohio, 44102, U.S.A.) (8). The Meriam Laminar-Flow Element incorporated in the new instrument (Model 50MJ10, Type 14) had no detectable decrease in pressure drop under artificially induced barometric pressure changes up to that occurring at $1800 \mathrm{~m}$ elevation ( $\sim 19 \%$ decrease in air density). It has several hundred capillary-flow paths in parallel arrangement.

The pressure drop in laminar flow is dependent on air viscosity. Air viscosity is mainly dependent on air temperature, and it is virtually independent of fluctuations in air pressure and relative humidity near ambient conditions $(9,10)$. A temperature increase of $2{ }^{\circ} \mathrm{C}$ from 22 to $24{ }^{\circ} \mathrm{C}$ causes a $0.7 \%$ increase in air viscosity. Thus, the influence of temperature on the calibration standard is small if relatively stable temperatures are encountered in the use of the instrument.

Recently, another proposal for the definition of pressure drop was submitted $(5,5$ a). There are few practical differences betweeen it and the definition adopted in 1971 if the main specification of both definitions $(17.5 \mathrm{ml} / \mathrm{s}$ air 
flow rate measured at the sample exit) is accepted. The major technical difference involves the location, relative to the sample, where certain air physical properties are specified. The 1971 definition specifies the barometric pressure $(760 \mathrm{mmHg})$, temperature $\left(22^{\circ} \mathrm{C}\right)$, and relative humidity $(60 \%)$ for air entering the sample. The recent proposal specifies these properties for air exiting the sample. Since the flow of air through cigarettes and filter rods is laminar (11) and if laminar-flow calibration standards are used to set the volumetric flow rate, the calibrated or measured pressure drops are independent of the density of the air as discussed before. Thus, the specification of barometric pressure may be disregarded for practical purposes. The effect of relative humidity on air density is small (12), and it may be disregarded also. As previously discussed, the most important air physical property specified where laminar flow is concerned, is air temperature, because of its effect on air viscosity. Whether it is specified at the sample entrance or the sample exit is inconsequential.

\section{Instrument}

The simplified equipment and flow diagram of the new pressure-drop instrument is shown in Figure 2. Note that the laminar-flow calibration standard is built into the air flow path downstream of the test sample in order to measure exit volumetric flow rate. The laminar-flow calibration standard is protected from contaminants in the air by Cambridge filter pads preceding it. Clean air is required for maintaining the calibration of the standard. Several types of sample holders can be used with the instrument. It will accommodate a Filtrona absolute test head for making encapsulated rod pressure-drop measurements, or conventional holders having either single or double rubber dams (13) that attach to the instrument with a tapered-joint fitting. Pressure-drop
Figure 3. Front-panel of the electronic pressure-drop instrument.

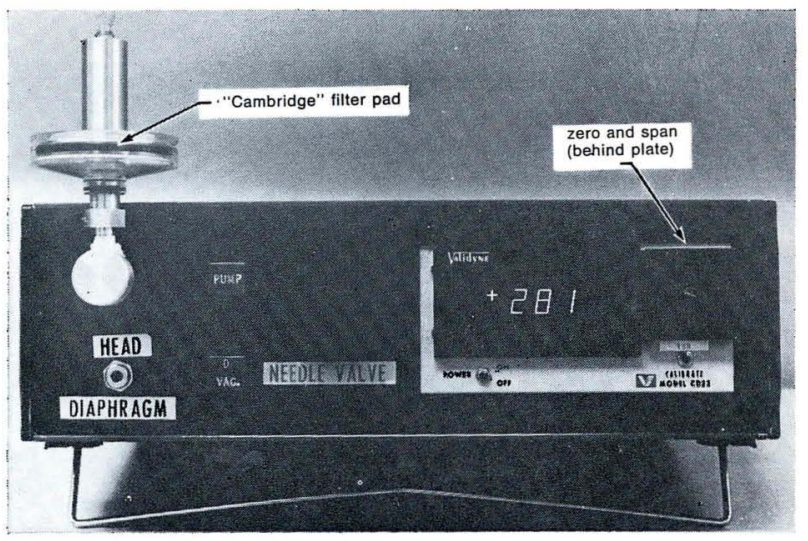

measurements are made using a digital manometer system manufactured by Validyne Engineering Corporation (19414 Londelius Street, Northridge, CA, 91324, U.S.A.). Two differential pressure transducers (D/P cells) are connected to the digital manometer: one for measuring the calibrated pressure drop of the laminarflow calibration standard, the other for measuring the sample pressure drop. The volumetric flow rate is adjusted using a micrometering valve that has high sensitivity in the desired flow-rate range. A surge tank is included to dampen vacuum supply surges. The source of vacuum is external to the instrument, and it is connected to the instrument through a quick-connect fitting.

Figure 3 shows the front panel of the instrument. On the left are two connections to the vacuum supply of the instrument. The upper vacuum connection for the test head contains a $70 \mathrm{~mm}$ Cambridge filter pad that can be easily changed periodically. (A similar filter pad is contained internally, immediately preceding the laminar-flow calibration standard.) The vacuum line for expanding the diaphragm of a Filtrona absolute test head

Figure 2. Simplified flow diagram of the electronic pressure-drop instrument.

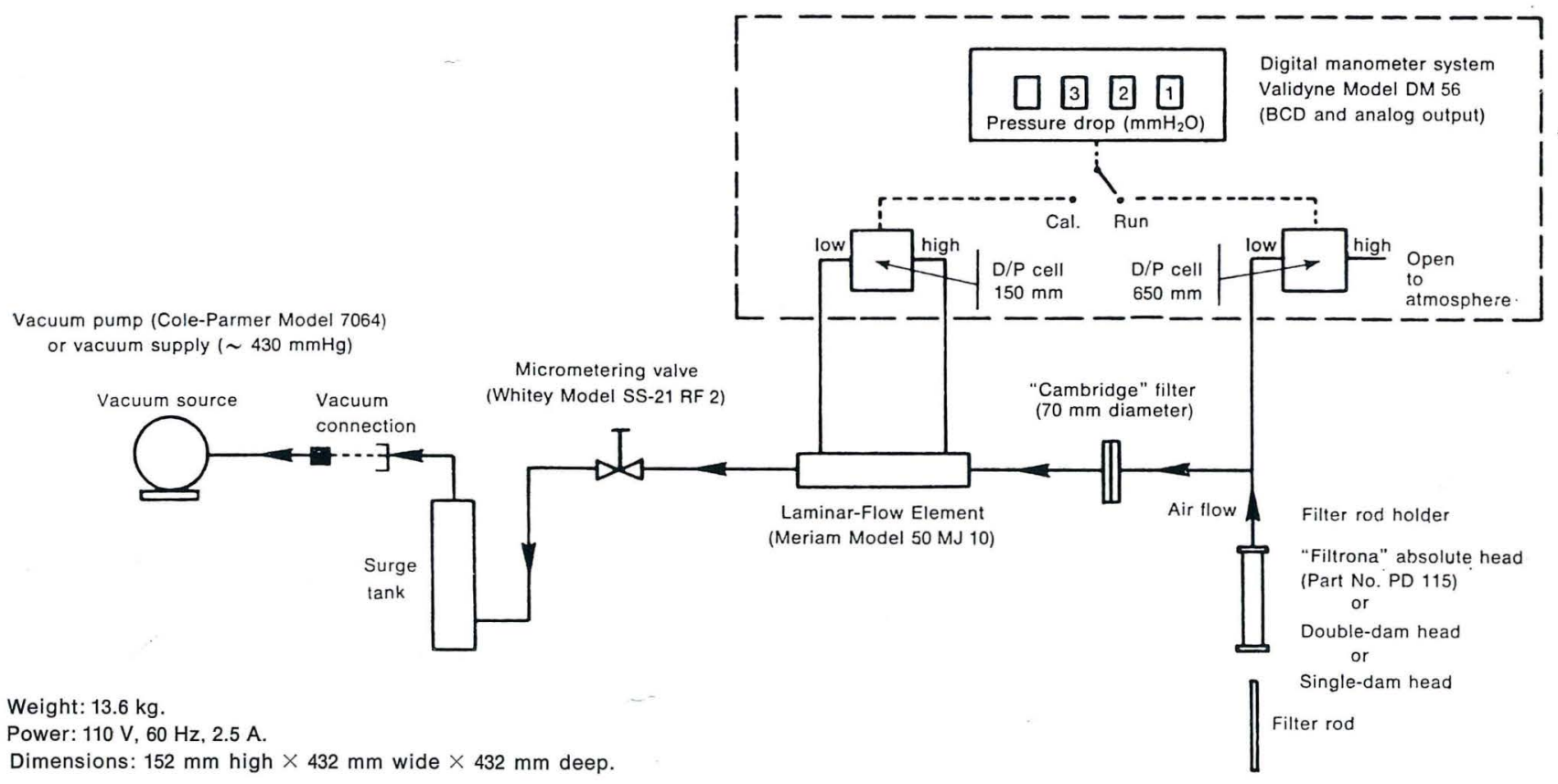


Figure 4. Interior of the electronic pressure-drop instrument.

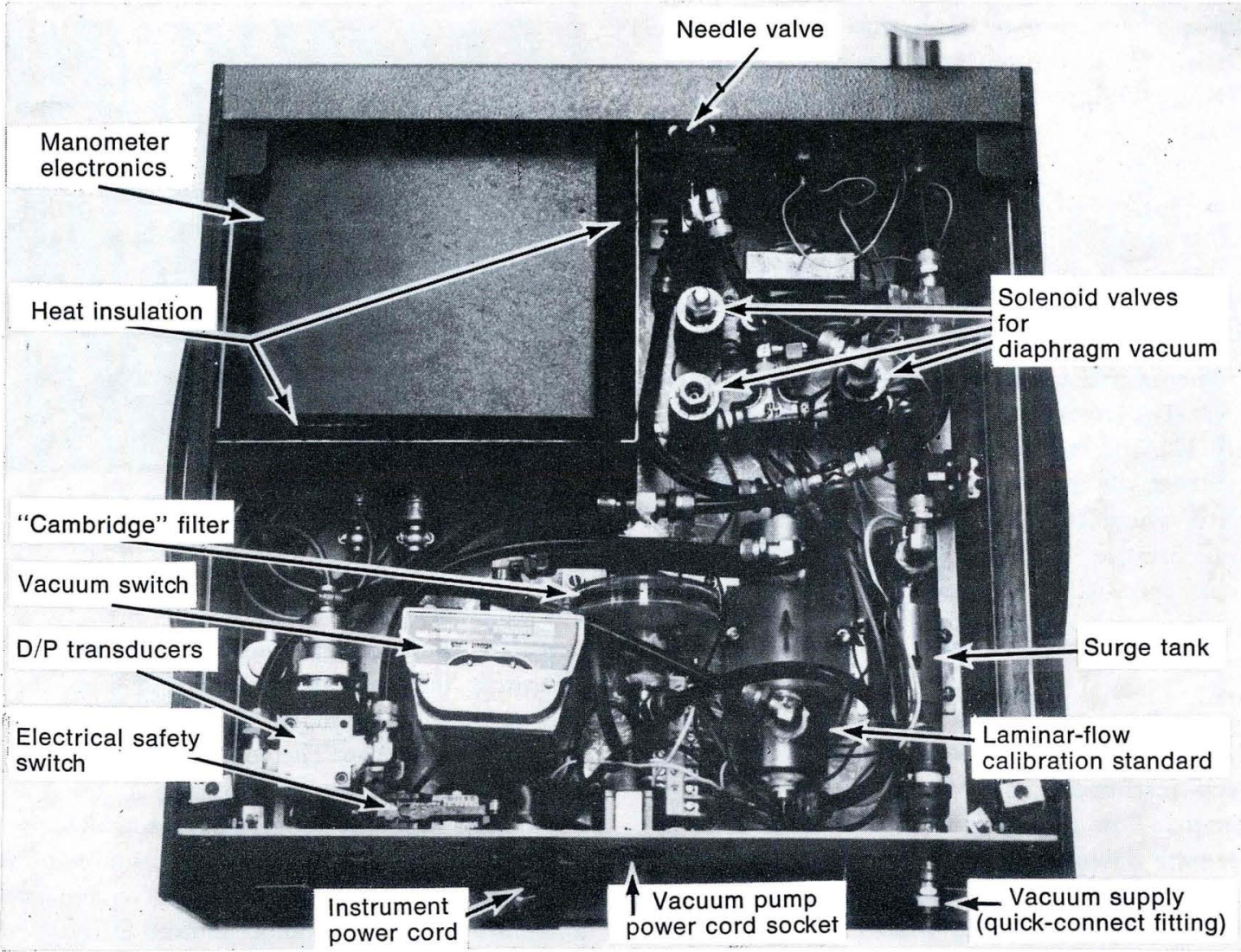

is connected through the lower quick-connect fitting. The switch, PUMP, applies $110 \mathrm{~V}$ power to a socket on the rear panel where a vacuum pump power cord may be attached. The switch, D.VAC., is a momentary switch that activates solenoid valves and diverts the vacuum supply to expand the test head diaphragm. The needle valve is centrally located for adjusting the volumetric flow rate. The digital manometer readout and controls are located to the right of the needle valve. The power to the manometer electronics is independent of the other instrument electronics, and it is controlled by the switch shown. Readout selection of the calibration standard pressure-drop transducer or the test sample pressuredrop transducer is made with the RUN-CALIBRATE toggle switch. The digital readout will read to the nearest millimeter of water pressure drop in the RUN mode and to the nearest tenth of a millimeter of water pressure drop in the calibrate mode. To the right of the digital readout behind a cover plate are zero and span controls for the transducers.

Figure 4 is a view of the interior of the instrument showing the location of several of the important components. The manometer electronics are surrounded by heat insulation. The electrical components are also ventilated by perforations in the top and bottom of the case (not shown). These precautions are taken to insure that the laminar-flow element maintains the temperature of the ambient air entering the instrument. An electrical safety switch is included so that the power supply is cut off when the case lid is removed.
A vacuum switch is included for transducer vacuum overrange protection.

Figure 5 shows the instrument connected to a Filtrona absolute test head.

\section{Instrument Operation}

After fabrication and prior to use, the zero and span controls for the transducers must be adjusted and the laminar-flow calibration standard pressure drop determined and recorded at the standard $17.5 \mathrm{ml} / \mathrm{s}$ exit volumetric flow rate. The span controls are set by using a water column manometer in parallel with the transducers or, in the case of the sample pressure-drop trans-

Figure 5. Electronic pressure-drop instrument connected to a Filtrona absolute test head.

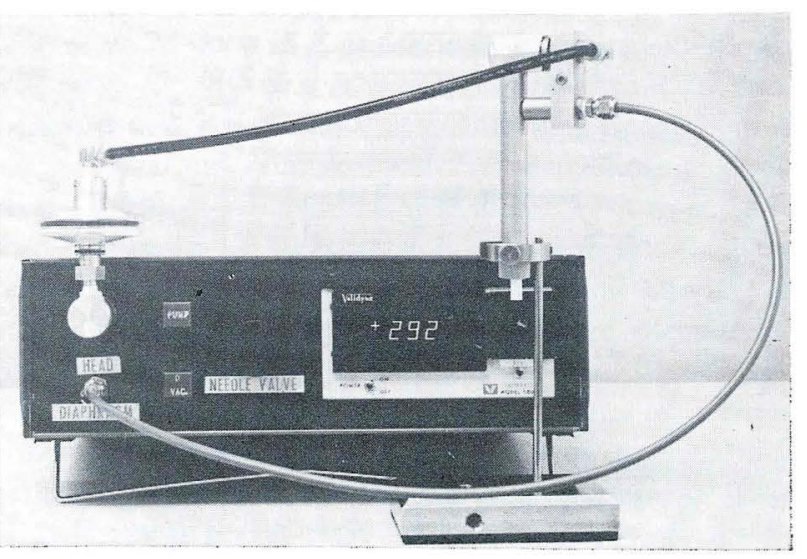


ducer, by using a pre-calibrated laminar-flow capillary standard having a pressure drop near the upper limit (650 $\mathrm{mm}$ of water) of the transducer range. The calibration standard pressure drop is then determined using a $600 \mathrm{ml}$ spirometer for measuring and setting the standard volumetric flow rate. The calibration pressure drop is recorded on the instrument so that in subsequent testing the proper flow rate can be set by selecting the CALIBRATE mode, then adjusting the needle valve so that the calibration pressure drop appears on the digital readout. Sample testing can then follow by returning to the RUN mode. Periodically, or when there is suspicion of instrument malfunction, the proper operation of the instrument can be checked using a set of precalibrated laminar-flow capillary standards. It is recommended that the digital manometer power be left on continuously to maximize electronic component stability.

The following procedure should be used in a sample measurement:

1. Attach the desired sample holder to the instrument.

2. Turn on the power to the vacuum pump or open the valve to the vacuum supply.

3. Insert the sample in the holder. (If the Filtrona absolute test head is being used, depress the D.VAC. button momentarily while inserting the sample in order to expand the diaphragm in the head.)

4. Select the Calibrate mode of operation by the toggle switch on the manometer.

5. Adjust the micrometering valve so that the precalibrated pressure drop of the laminar-flow calibration standard is obtained on the manometer digital readout.

6. Select the RUN mode of operation.

7. Read the sample pressure drop on the manometer digital readout.

8. Check the operation of the unit when needed with a laminar-flow capillary standard having a known pressure drop.

Steps 4 and 5 need to be repeated only when sample pressure drops vary widely (usually $>150 \mathrm{~mm}$ of water difference).

\section{RESULTS AND DISCUSSION}

Table 1 shows the results of tests conducted simultaneously on the new instrument and the previously used manometer-type instrument. Data from the new instrument compare favorably with data obtained from the previously used instrument. The new instrument has operated more than a year without significant maintenance.

The most significant improvement incorporated in the design of the instrument is the inclusion of a built-in laminar-flow calibration standard. The pressure drop of the laminar-flow calibration standard is not sensitive to air density changes at the standard flow rate. Thus, it can be used to set the proper exit volumetric
Table 1. Pressure-drop statistics $\left(\mathrm{mmH}_{2} \mathrm{O}\right)-25$-rod sample, double-dam head.

\begin{tabular}{lc|c|c|c}
\cline { 2 - 5 } & \multicolumn{2}{c|}{$\begin{array}{c}3.3 / 42,000-N o .10 \\
100 \mathrm{~mm} \text { rods }\end{array}$} & \multicolumn{2}{c}{$\begin{array}{c}1.6 / 48,000-R \\
100 \mathrm{~mm} \text { rods }\end{array}$} \\
\cline { 2 - 6 } & $\begin{array}{c}\text { New } \\
\text { electronic } \\
\text { instrument }\end{array}$ & $\begin{array}{c}\text { Con- } \\
\text { ventional } \\
\text { manometer }\end{array}$ & $\begin{array}{c}\text { New } \\
\text { electronic } \\
\text { instrument }\end{array}$ & $\begin{array}{c}\text { Con- } \\
\text { ventional } \\
\text { manometer }\end{array}$ \\
\hline$\overline{\mathrm{x}}\left(\mathrm{mmH}_{2} \mathrm{O}\right)$ & 312.1 & 313.6 & 473.0 & 474.6 \\
S.D. ${ }^{*}$ & 5.28 & 5.19 & 10.12 & 9.85 \\
$\begin{array}{l}\text { Coefficient of } \\
\text { variation }(\%)\end{array}$ & 1.69 & 1.65 & 2.14 & 2.08 \\
\hline
\end{tabular}

* standard deviation.

flow rate without regard to ambient conditions, e.g. altitude, weather conditions or the pressure drop of the sample. Also, the built-in calibration standard offers virtual independence from the use of external capillary standards and the associated problems of handling capillaries and capillary cleanliness and maintenance of calibration. It provides a simple, easy method of adjusting the flow rate when widely different sample pressure drops are measured.

The response time of the pressure-drop transducers in the digital manometer is significantly less than that of water column manometers. Thus, substantial time is saved in pressure-drop measurement. There has been less reading error with the digital readout of the new instrument. Binary coded decimal (BCD) and analog data outputs are included on the digital manometer. These outputs provide potential for automated data processing.

If sufficient data acquisition and data analysis capability is available for use with the instrument, data taken at non-standard flow rates could be corrected to data equivalent to that taken at the standard flow rate. This technique would eliminate needle valve adjustment for different sample pressure drops. Data could be collected simultaneously on flow rate (by reading the calibration standard pressure drop) and sample pressure drop. Then the sample pressure drop could be corrected to its value at the standard flow rate. A direct correction method might involve a valve positioner for the needle valve which would operate when the calibration standard pressure drop deviated from its calibration value.

\section{SUMMARY}

A compact, portable pressure-drop instrument that incorporates modern electronic pressure-drop measuring techniques has been designed and built. It includes a built-in laminar-flow calibration standard. The new design offers virtual independence from external capillary standards (and the associated problems of maintaining capillary cleanliness), fast digital readout, potential for automatic data processing, and a simple method of flow-rate adjustment at different filter rod pressure drops. Pressure drop measured with the new 
instrument meets the Coresta ${ }^{*}$-recommended definition of pressure drop for filter rods. Data collected on the new instrument show that the average and percent coefficient of variation of pressure drops measured on the new instrument compare favorably with data collected by the previously used standard instrument having mainly a vacuum pump, needle valve and water column manometer.

\section{ZUSAMMENFASSUNG}

Es wird ein kompaktes, transportables Zugwiderstandsmeßgerät, das moderne elektronische Druckmeßtechnik anwendet, beschrieben. In dem Gerät wird zum Messen des Volumenflusses ein Strömungswiderstand bei laminarem Fluß benutzt. Dadurch ist man unabhängig von Eichkapillaren und damit verbundenen Reinigungsproblemen. Die Meßwerte werden digital schnell angezeigt und stehen an einem Ausgang zur automatischen Datenverarbeitung an. Das Gerät ermöglicht ferner eine einfache Meßbereichseinstellung für unterschiedliche Zugwiderstände von Filterstäben. Die Zugwiderstandsmessung mit dem neuen Gerät entspricht der von der Coresta* empfohlenen Definition des Zugwiderstandes von Filterstäben. Vergleichsmessungen zeigen, daß die Mittelwerte und Variationskoeffizienten, die man bei Messungen mit dem neuen Gerät erhält, gut vergleichbar sind mit denen, die man mit herkömmlichen Standardgeräten erhält, welche hauptsächlich aus einer Vakuumpumpe, einem Nadelventil und einem Wassermanometer bestehen.

\section{RÉSUMÉ}

Un instrument compact et portatif pour la détermination de la résistance au tirage a été construit, en y incorporant des éléments électroniques modernes de mesure de la pression différentielle. L'instrument comprend un étalon de flux laminaire. Ceci rend son emploi indépendant d'étalons capillaires externes et élimine le problème de nettoyage de ces derniers. La lecture se fait par affichage digital rapide, avec la possibilité d'un traitement automatique des données. L'instrument permet le choix aisé de la plage de mesure pour les différentes résistances au tirage des bâtonnets filtres. La mesure de la résistance au tirage avec ce nouvel instrument correspond à la définition de la résistance au tirage des bâtonnets filtres recommandée par Coresta*. Des valeurs déterminées avec cet appareil, il ressort que les moyennes et les coefficients de variation sont du même ordre que ceux obtenus sur un instrument standard traditionnel, se composant en principe d'une pompe à vide, d'une valve à pointeau et d'un manomètre à eau.

\section{REFERENCES}

1. Papers on draw resistance of tobacco products (1942-1975); Coresta Information Bulletin 1977-1,

\footnotetext{
* Cooperation Centre for Scientific Research Relative to Tobacco, Paris.
}

20-33 as well as Beitr. Tabakforsch. Int. 9 (1978), 256-261.

2. Bethmann, M. von, and H. Böttcher: Evaluation of the second collaborative study on the comparability of three methods for measuring pressure drop of filter rods; Coresta Information Bulletin 1970-1, 3-26.

2a. Bethmann, M. von, and H. Böttcher: Auswertung der 2. Coresta-Ringuntersuchung über die Vergleichbarkeit von drei ausgewählten Meßmethoden für den Zugwiderstand von Filterstäben; Beitr. Tabakforsch. 5 (1970), 239-252.

3. Flesselles, J.: Checking apparatus for measuring pressure drop; Coresta Information Bulletin 1974$1,23-30$.

4. Unpublished circular issued to those attending the Coresta Technology Study Group meeting held in Rome in 1971.

5. $\mathrm{ISO}^{+} / \mathrm{TC} 126-\mathrm{SC} 1$ and Coresta Technology Study Group: Proposal for the definition of the term "draw resistance"; Coresta Information Bulletin 1977-1, 17-33.

5a. Gehring, M.: Vorschlag für die Definition des Zugwiderstandes; Beitr. Tabakforsch. Int. 9 (1978), 255-261.

6. Schlichting, H.: Boundary layer theory, 4th ed; McGraw-Hill Book Company, Inc., New York, 1960, pp. 10-14.

7. Kreith, F., and R. Eisenstadt: Pressure drop and flow characteristics of short capillary tubes at low Reynolds numbers; Transactions of the American Society of Mechanical Engineers 79 (1957), 10701078.

8. Laminar flow meters; Publication issued by Meriam Instrument Company, Cleveland, Ohio, U.S.A., 44102, File No. 501:215-1.

9. Schlichting, H.: Boundary layer theory, 4th ed.; McGraw-Hill Book Company, Inc., New York, 1960, p. 7.

10. Handbook of fundamentals, 1st ed.; American Society of Heating, Refrigeration, Air Conditioning Engineers, New York, 1967, pp. 108-109.

11. Strydom, M. L., and J. P. Otto: Investigating whether the air flow through cigarettes and filter rods has laminar or turbulent characteristics; $\mathrm{Co}_{\mathrm{O}}$ resta Information Bulletin 1972-2, 12-16.

12. Baumeister, T. (ed.): Mark's mechanical engineers handbook, 6th ed.; McGraw-Hill Book Company, Inc., New York, 1958, pp. 4-82 - 4-85.

13. Kiefer, J. E., and C. H. Weatherly: New head for cigarette filter rod pressure drop instrument; Tob. Sci. 19 (1975), 86.

Author's address:

Tennessee Eastman Company, Research Laboratories, Kingsport, Tennessee, 37662, U.S.A.

\footnotetext{
+ International Organization for Standardization.
} 